\title{
Tolerance of Winter Wheat to Co-application of Postemergence Broadleaf Herbicides Using Urea Ammonium Nitrate as the Carrier
}

\author{
K.D. Walsh, L.R. Brown, N. Soltani* and P.H. Sikkema \\ Department of Plant Agriculture, University of Guelph Ridgetown Campus, Ridgetown, Ontario, N0P 2C0, Canada
}

\begin{abstract}
Spring application of post-emergence (POST) broadleaf herbicides in a urea ammonium nitrate (UAN) as the carrier may provide winter wheat growers with a one-pass option for weed control and nitrogen application. Winter wheat tolerance to bromoxynil/MCPA, dichlorprop/2,4-D, thifensulfuron/tribenuron + MCPA amine or pyrasulfotole/bromoxynil applied using 28\% UAN at various carrier volumes $\left(0,100,200,300\right.$ and $\left.400 \mathrm{~L} \mathrm{ha}^{-1}\right)$ was evaluated in field experiments planted in the fall of 2008, 2009 and 2010 at Exeter and Ridgetown Ontario, Canada. Generally, winter wheat injury was greater as the carrier volume of UAN increased. Injury due to bromoxynil/MCPA, dichlorprop/2,4-D, thifensulfuron/tribenuron + MCPA amine and pyrasulfotole/bromoxynil was as much as $8,11,18$ and $9 \%$ at 7 days after treatment (DAT); the injury observed was transient and was 1, 2, 4 and $1 \%$ at 28 DAT, respectively. Winter wheat height and yield were not reduced by the herbicides evaluated, excepting bromoxynil/MCPA which reduced yield by $2 \%$, and thifensulfuron/tribenuron + MCPA amine, which reduced height $3 \%$ and yield $2 \%$. The establishment of underseeded red clover was decreased by at least $50 \%$ for all herbicide treatments assessed, except bromoxynil/MCPA. Based on this study, there is potential for spring co-application of UAN and bromoxynil/MCPA, dichlorprop/2,4-D, thifensulfuron/tribenuron + MCPA amine or pyrasulfotole/bromoxynil in winter wheat. However, growers that underseed red clover may not fully benefit as carrier UAN significantly reduced clover establishment.
\end{abstract}

Keywords: Red clover, urea ammonium nitrate, winter wheat.

\section{INTRODUCTION}

Winter wheat (Triticum aestevum L.) is one of Canada's major cereal crops, comprising over 700,000 hectares [1]. High yields, competitive pricing and adaptability to various soil types have made this cereal crop the choice of many Canadian growers [2]. Unlike spring-planted cultivars, winter wheat is seeded in the autumn, overwinters as a seedling and reaches maturity in mid-summer of the following calendar year. Its prolonged growing season and influx of early spring moisture can contribute to yields that are up to $30 \%$ higher than spring wheat [2, 3]. In central Canada, winter wheat is typically grown following soybean [Glycine max (L.) Merr.]. As part of a sustainable approach, some growers underseed red clover (Trifolium pretense L.) in their winter wheat crop to fix soil nitrogen and to help offset the large nitrogen demand of the succeeding corn (Zea mays L.) crop in the rotation [4, 5]. Winter wheat exhibits vigorous spring growth therefore crop inputs and intensive management are most effective prior to canopy closure.

Spring management of nitrogen fertility and weed infestations are important considerations in profitable winter wheat production. A healthy winter wheat crop will resume growth early in the spring and require application of nitrogen to boost yield. Urea ammonium nitrate (UAN) is a liquid nitrogen fertilizer that is resistant to volatilization losses and is often applied in winter wheat crops $[1,6]$. Broadleaf

*Address correspondence to this author at the University of Guelph Ridgetown Campus, Ridgetown, Ontario, N0P 2C0, Canada;

Tel: 519-674-1500; Fax: 519-674-1600;

E-mail: soltanin@uoguelph.ca post-emergence (POST) weed control in winter wheat has traditionally included bromoxynil/MCPA, dichlorprop/2,4-D and thifensulfuron/tribenuron + MCPA however, new chemistries including pyrasulfotole/bromoxynil have recently become commercially available [7]. Spring broadleaf weed control applications should be done prior to canopy closure and may coincide with nitrogen applications. As a result, sequential application of fertilizer and herbicide can be costly in terms of time and resources for winter wheat producers.

Co-application of a POST herbicide in UAN as the carrier has potential to optimize efficiency of field operations in winter wheat cultivation. Typically, UAN is applied with streamer nozzles that minimize leaf injury. Delivery of a foliar herbicide using streamer nozzles will not provide adequate coverage of target weeds, therefore a successful onepass system requires application via flat fan or flood nozzles to ensure maximum herbicide efficacy. Edwards et al. [6] previously reported that low rates of UAN could be effectively applied with flood nozzles. However, Stahlman et al. [8] found that utilisation of UAN as a herbicide carrier caused greater damage than application of UAN alone. At this time, more research is needed to assess the feasibility of using UAN as the carrier for winter wheat herbicide applications.

The objective of this study was to determine if spring coapplication of bromoxynil/MCPA, dichlorprop/2,4-D, thifensulfuron/tribenuron + MCPA amine or pyrasulfotole/bromoxynil with UAN as the herbicide carrier in winter wheat would limit establishment of underseeded red clover or result in increased wheat injury, or reduced plant height and yield. 


\section{MATERIALS AND METHODS}

In the fall of 2008, 2009 and 2010, field experiments were planted near Exeter, at the Huron Research Station and in the fall of 2010 at the University of Guelph, Ridgetown Campus, near Ridgetown, Ontario, Canada. Soil characteristics are summarised in (Table 1).

The experimental design was a two-way factorial arranged in a randomized complete block, with four replications. Factor one was herbicide treatment and factor two was UAN carrier volume. Herbicide treatments included a untreated check, bromoxynil/MCPA (560 g a.i. ha $\left.{ }^{-1}\right)$, dichlorprop/2,4-D (1017 g a.i. ha $\left.{ }^{-1}\right)$, thifensulfuron/tribenuron $\left(15 \mathrm{~g}\right.$ a.i. ha $\left.{ }^{-1}\right)$ plus MCPA amine $\left(550 \mathrm{~g}\right.$ a.i. $\left.\mathrm{ha}^{-1}\right)$ and nonionic surfactant (Agral $\left.90^{\circledR}, 0.2 \% \mathrm{vol} / \mathrm{vol}\right)$, and pyrasulfotole/bromoxynil (213 g a.i. ha $\left.{ }^{-1}\right)$ plus ammonium sulfate $\left(1.0 \mathrm{~L} \mathrm{ha}^{-1}\right)$; UAN was applied at $0,100,200,300$ and $400 \mathrm{~L}$ $\mathrm{ha}^{-1}$. Dry nitrogen fertilizer (46-0-0) was applied to each plot so that the total amount of nitrogen was $112 \mathrm{~kg} \mathrm{ha}^{-}$ across the entire experimental area. Plot dimensions were 10 by $2 \mathrm{~m}$ at Exeter and 8 by $2 \mathrm{~m}$ at Ridgetown. Soft red winter wheat (SRWW) 'Pioneer 25R47' was planted at a 4 $\mathrm{cm}$ depth using a double disc drill at $150 \mathrm{~kg} \mathrm{ha}^{-1}$ with 17.5 $\mathrm{cm}$ row spacing, from mid-September to late October; common red clover was broadcasted at a rate of $11 \mathrm{~kg} \mathrm{ha}^{-1}$ the subsequent March to April. Herbicide/UAN treatments were applied late April to early May. Treatments were applied using a $\mathrm{CO}_{2}$-pressurized backpack sprayer (Bellspray, Inc. Opelousas, USA) with four ultra-low drift nozzle tips (ULD 120-04;Hypro, New Brighton, USA), spaced $50 \mathrm{~cm}$ apart. The sprayer was adjusted to deliver $400 \mathrm{~L} \mathrm{ha}^{-1}$ aqueous solution at $240 \mathrm{kPa}$. Plots were kept free of weeds by hoeing as needed.

Winter wheat injury was visually scored on a scale of 0 (no injury present) to $100 \%$ (complete plant death) at 7, 14, 21 and 28 days after treatment (DAT). Wheat height was measured for ten random plants per plot at 56 DAT and averaged. Wheat head distortion was visually assessed on a scale of 0 (no distortion present) to $100 \%$ (complete distortion) just prior to harvest. Plots were harvested with a small plot combine and moisture and weight were recorded; based on which yields were adjusted to $14 \%$ moisture. Clover establishment at 112 DAT was rated on a scale of 0 (bare ground) to 10 (equivalent to the untreated check). Clover dry weight was evaluated 112 DAT by excising plants at the soil surface from $0.5 \mathrm{~m}^{2}$ per plot. Plants were dried to constant moisture at $60{ }^{\circ} \mathrm{C}$ and then weighed.
Data were analysed as a two-way factorial using Proc Mixed in SAS 9.2 [9]. The two treatment factors, herbicide treatment and UAN carrier volume, as well as their interaction were considered fixed effects, while environment (yearlocation combinations), interactions between environment and the fixed effects, and replicate nested within environment were considered random effects. Environments were combined for all variables. Fixed effect significance and random effects were established using $F$-tests and a $Z$-test of the variance estimate, respectively. The Univariate procedure was used to test data for normality and homogeneity of variance. To satisfy the assumptions of the variance analyses, injury 7 and 14 DAT and clover establishment were square-root-transformed, injury 21 DAT and clover dry weight were $\log$ transformed. Treatment comparisons were made using Fisher's Protected LSD test. All statistical comparisons were made using a Type I error of 0.05. All data transformations made to facilitate comparison were transformed back to their original scale for tabular presentation.

\section{RESULTS AND DISCUSSION}

The amount of precipitation received at all trial sites was generally at or above the 30-yr average, for April and May (Table 2). When applied post-seeding, the efficacy of UAN is highly dependent upon receipt of some precipitation postapplication to ensure that the product moves into the soil [10]. Moreover, there was no significant dose by environment interaction and thus no trial site required individual analysis.

No wheat head distortion was observed just prior to harvest for any of the herbicide or UAN combinations (data not shown). Analysis of the main effects indicated that winter wheat injury caused by bromoxynil/MCPA, dichlorprop/2, 4$\mathrm{D}$, thifensulfuron/tribenuron + MCPA amine and pyrasulfotole/bromoxynil was highly significant at 7, 14, 21 and 28 DAT (Table 3). Initially, winter wheat injury, attributed to herbicide treatment, was moderate ranging from 5 to $10 \%$ at 7 DAT (Table 3). However, injury was temporary and decreased to less than, 7, 3 and $3 \%$ at 14,21 and 28 DAT, respectively (Table $\mathbf{3}$ ).

Winter wheat injury, due to UAN treatment, was highly significant at 7, 14 and 21 DAT (Table 3). Similar to herbicide treatment, injury was highest immediately following application but declined as DAT increased, ranging from 4 to 10,2 to 7,1 to 3 and 1 to $2 \%$ for 7, 14, 21 and 28 DAT, respectively (Table 3). Likewise, Soltani et al. [11] reported $5 \%$ winter wheat injury 7 DAT when $28 \%$ UAN

Table 1. Location and soil information for experiments conducted during 2008 to 2010 .

\begin{tabular}{|c|c|c|c|c|c|c|c|}
\hline Year & Location & Soil texture & Sand & Silt & Clay & OM & $\mathbf{p H}$ \\
\hline 2009 & Exeter & Brookston clay loam & 35 & 43 & 22 & 3.8 & 7.7 \\
\hline 2010 & Exeter & Brookston clay loam & 17 & 47 & 36 & 3.6 & 7.9 \\
\hline
\end{tabular}


Table 2. Mean and 30-yr average precipitation data for McGregor and Windsor in 2012 and McGregor, Harrow, and Tilbury in 2013, in Ontario from May to August ${ }^{\mathrm{a}}$.

\begin{tabular}{|c|c|c|c|c|c|c|c|c|c|}
\hline \multicolumn{2}{|c|}{ Environment } & \multicolumn{2}{|c|}{ April } & \multicolumn{2}{|c|}{ May } & \multicolumn{2}{|c|}{ June } & \multicolumn{2}{|c|}{ July } \\
\hline \multirow{2}{*}{ Year } & \multirow{2}{*}{ Location } & Mean & 30-yr avg. & Mean & 30-yr avg. & Mean & 30-yr avg. & Mean & 30-yr avg. \\
\hline & & \multicolumn{8}{|c|}{$\mathbf{m m}$} \\
\hline 2009 & Exeter & 80 & - & 93 & 94 & 68 & 62 & 50 & 61 \\
\hline 2010 & Exeter & 29 & - & 69 & 94 & 185 & 62 & 88 & 61 \\
\hline 2011 & Exeter & 93 & - & 135 & 94 & 88 & 62 & 34 & 61 \\
\hline 2011 & Ridgetown & 155 & 78 & 180 & 75 & 83 & 83 & 155 & 86 \\
\hline
\end{tabular}

a 30-yr average precipitation and data from Farmzone 2014.

Table 3. Winter wheat percent injury, height and yield as well as red clover establishment and dry weight, treated with four different postemergence herbicides using UAN at different carrier volumes. Within each column, means followed by the same letter (a-d) do not significantly differ according to Fisher's Protected LSD at $\mathbf{P}<0.05$. ${ }^{\text {ab }}$

\begin{tabular}{|c|c|c|c|c|c|c|c|c|c|c|c|c|c|}
\hline \multirow{4}{*}{ Main Effects ${ }^{c}$} & \multicolumn{9}{|c|}{ Winter Wheat Injury } & \multicolumn{4}{|c|}{ Red Clover Injury $^{d}$} \\
\hline & \multicolumn{5}{|c|}{ Days After Treatment } & \multirow{2}{*}{\multicolumn{2}{|c|}{ Height }} & \multirow{2}{*}{\multicolumn{2}{|c|}{ Yield }} & \multirow{2}{*}{\multicolumn{2}{|c|}{ Establishment }} & \multirow{2}{*}{\multicolumn{2}{|c|}{ Dry Weight }} \\
\hline & 7 & 14 & \multicolumn{2}{|c|}{21} & 28 & & & & & & & & \\
\hline & \multicolumn{5}{|c|}{$\%$ Injury } & \multicolumn{2}{|c|}{$\mathrm{Cm}$} & \multicolumn{2}{|c|}{ MT ha ${ }^{-1}$} & & & \multicolumn{2}{|c|}{$\mathbf{g}$} \\
\hline Herbicide treatment $\S$ & $* *$ & $* *$ & \multicolumn{2}{|c|}{$* *$} & $* *$ & \multicolumn{2}{|c|}{ * } & \multicolumn{2}{|c|}{$*$} & \multicolumn{2}{|c|}{$* *$} & \multicolumn{2}{|c|}{$* *$} \\
\hline No herbicide & 2.9 & 1.6 & 0.5 & $\mathrm{a}$ & 0.6 & 79 & $\mathrm{a}$ & 6.8 & $\mathrm{a}$ & 9 & $\mathrm{a}$ & 22.4 & $\mathrm{a}$ \\
\hline Bromoxynil/MCPA & 4.6 & 2.6 & 0.8 & $\mathrm{~b}$ & 0.8 & 79 & $\mathrm{a}$ & 6.7 & $\mathrm{bc}$ & 7 & a & 9.5 & $\mathrm{~b}$ \\
\hline Dichlorprop/2,4-D & 5.9 & 3.9 & 1.4 & $\mathrm{c}$ & 0.9 & 79 & $\mathrm{a}$ & 6.8 & $\mathrm{ab}$ & 2 & $\mathrm{~b}$ & 1.4 & cd \\
\hline $\begin{array}{l}\text { Thifensulfuron/tribenuron }+ \\
\text { MCPA amine }\end{array}$ & 9.7 & 6.5 & 2.7 & $\mathrm{~d}$ & 2.4 & 77 & $\mathrm{~b}$ & 6.7 & $\mathrm{c}$ & 3 & $\mathrm{~b}$ & 2.1 & $\mathrm{c}$ \\
\hline Pyrasulfotole/bromoxynil & 4.6 & 3.0 & 0.9 & $\mathrm{bc}$ & 0.9 & 79 & $\mathrm{a}$ & 6.8 & $a b$ & 1 & c & 0.5 & d \\
\hline $\mathrm{SE}$ & 0.2 & 0.2 & \multicolumn{2}{|c|}{0.1} & 0.1 & \multicolumn{2}{|c|}{0} & \multicolumn{2}{|c|}{0.1} & \multicolumn{2}{|c|}{0} & \multicolumn{2}{|c|}{1.0} \\
\hline UAN treatment & $* *$ & $* *$ & \multicolumn{2}{|c|}{$* *$} & NS & \multicolumn{2}{|c|}{ NS } & \multicolumn{2}{|c|}{ NS } & \multicolumn{2}{|c|}{$* *$} & \multicolumn{2}{|c|}{$* *$} \\
\hline No UAN & 0.7 & 0.2 & 0.1 & a & 0.2 & \multicolumn{2}{|c|}{79} & \multicolumn{2}{|c|}{6.8} & 5 & $\mathrm{a}$ & 7.2 & $\mathrm{a}$ \\
\hline $100 \mathrm{~L}$ UAN & 3.9 & 2.4 & 0.7 & $b$ & 0.7 & \multicolumn{2}{|c|}{79} & \multicolumn{2}{|c|}{6.9} & 4 & $\mathrm{~b}$ & 3.7 & $b$ \\
\hline 200 L UAN & 6.9 & 3.8 & 1.3 & $\mathrm{bc}$ & 1.1 & & & & & 4 & $\mathrm{~b}$ & 3.2 & $\mathrm{~b}$ \\
\hline 300 L UAN & 8.1 & 5.6 & 1.9 & $\mathrm{~cd}$ & 1.7 & & & & & 4 & $\mathrm{~b}$ & 3.2 & $\mathrm{~b}$ \\
\hline 400 L UAN & 10.0 & 6.8 & 2.6 & d & 1.9 & & & & & 4 & $\mathrm{~b}$ & 3.0 & $\mathrm{~b}$ \\
\hline $\mathrm{SE}$ & 0.2 & 0.2 & & & 0.1 & & & & & & & & \\
\hline Interaction & & & & & & & & & & & & & \\
\hline Herbicide $\mathrm{x}$ UAN & $*$ & $*$ & & & $*$ & & & & & & & & \\
\hline
\end{tabular}

${ }^{a}$ Abbreviations: UAN, urea ammonium nitrate

${ }^{\mathrm{b}}$ Means presented have been transformed back to the original scale. Main effects were separated only where no significant interaction concerning that main effect was present.

${ }^{c}$ Significance at $P<0.05$ and $P<0.01$ levels represented by * and $* *$, respectively. Non-ionic surfactant added to thifensulfuron/tribenuron + MCPA amine $(0.2 \%$ v/v); ammonium sulfate added to pyrasulfotole/bromoxynil $\left(1.0 \mathrm{~L} \mathrm{ha}^{-1}\right)$

${ }^{\mathrm{d}}$ Clover establishment was rated on a scale of 0 to 10 ; where 0 was bare ground and 10 was equivalent to the untreated check. Cover dry weight corresponds to a $0.5 \mathrm{~m}^{2}$ harvested area. 
Table 4. Percent injury 7, 14 and 28 DAT of winter wheat with five carrier volumes of UAN and four postemergence herbicides. Within each column (a-d) and row (W-Z), means followed by the same letter, in each section, do not significantly differ according to Fisher's Protected LSD at $\mathbf{P}<0.05$.

\begin{tabular}{|c|c|c|c|c|c|c|c|c|c|c|c|c|c|c|c|c|}
\hline Herbicide Treatment ${ }^{b}$ & \multicolumn{15}{|c|}{ UAN Carrier Volume } & SE \\
\hline \multicolumn{17}{|l|}{ Injury $7 D A T$} \\
\hline No herbicide & 0.0 & $\mathrm{a}$ & Z & 2.0 & $\mathrm{a}$ & $\mathrm{Y}$ & 3.8 & $\mathrm{a}$ & $\mathrm{X}$ & 4.9 & $\mathrm{a}$ & WX & 5.9 & $\mathrm{a}$ & $\mathrm{W}$ & 0.3 \\
\hline Dichlorprop/2,4-D & 1.4 & $\mathrm{c}$ & Z & 3.8 & $\mathrm{~b}$ & $\mathrm{Y}$ & 7.8 & c & $\mathrm{X}$ & 8.2 & $\mathrm{~b}$ & $\mathrm{X}$ & 10.7 & $\mathrm{c}$ & $\mathrm{W}$ & 0.4 \\
\hline $\begin{array}{l}\text { Thifensulfuron/tribenuron } \\
+ \text { MCPA amine }\end{array}$ & 1.6 & $\mathrm{c}$ & Z & 8.1 & $\mathrm{c}$ & $\mathrm{Y}$ & 11.7 & $\mathrm{~d}$ & $\mathrm{X}$ & 14.2 & $\mathrm{c}$ & $\mathrm{X}$ & 17.8 & $\mathrm{~d}$ & $\mathrm{~W}$ & 0.7 \\
\hline Pyrasulfotole/bromoxynil & 0.3 & $a b$ & Z & 3.2 & $\mathrm{~b}$ & $\mathrm{Y}$ & 6.2 & $\mathrm{bc}$ & $\mathrm{X}$ & 7.4 & $\mathrm{~b}$ & $\mathrm{X}$ & 9.2 & $\mathrm{bc}$ & $\mathrm{W}$ & 0.4 \\
\hline No herbicide & 0.0 & $\mathrm{a}$ & $\mathrm{Z}$ & 0.8 & $\mathrm{a}$ & $\mathrm{Y}$ & 1.4 & $\mathrm{a}$ & $\mathrm{Y}$ & 3.0 & $\mathrm{a}$ & $\mathrm{X}$ & 4.1 & $\mathrm{a}$ & $\mathrm{X}$ & 0.2 \\
\hline Bromoxynil/MCPA & 0.0 & $\mathrm{a}$ & Z & 1.7 & $\mathrm{ab}$ & $\mathrm{Y}$ & 3.2 & $\mathrm{~b}$ & $\mathrm{X}$ & 4.4 & $\mathrm{~b}$ & WX & 5.8 & $\mathrm{~b}$ & $\mathrm{~W}$ & 0.3 \\
\hline Dichlorprop/2,4-D & 0.5 & $a b$ & Z & 2.8 & $\mathrm{c}$ & $\mathrm{Y}$ & 4.7 & $\mathrm{c}$ & $\mathrm{X}$ & 6.0 & $\mathrm{c}$ & WX & 7.3 & $\mathrm{~b}$ & $\mathrm{~W}$ & 0.4 \\
\hline $\begin{array}{l}\text { Thifensulfuron/tribenuron } \\
+ \text { MCPA amine }\end{array}$ & 0.8 & $\mathrm{~b}$ & Z & 5.7 & $\mathrm{~d}$ & $\mathrm{Y}$ & 7.8 & $\mathrm{~d}$ & $\mathrm{X}$ & 10.0 & $\mathrm{~d}$ & W & 11.5 & $\mathrm{c}$ & $\mathrm{W}$ & 0.5 \\
\hline Pyrasulfotole/bromoxynil & 0.0 & $\mathrm{a}$ & Z & 2.2 & $\mathrm{bc}$ & $\mathrm{Y}$ & 3.4 & $\mathrm{~b}$ & $\mathrm{Y}$ & 5.5 & $\mathrm{bc}$ & $\mathrm{X}$ & 6.3 & $\mathrm{~b}$ & $\mathrm{X}$ & 0.3 \\
\hline SE & 0.1 & & & 0.3 & & & 0.3 & & & 0.4 & & & 0.3 & & & \\
\hline \multicolumn{17}{|l|}{ Injury $28 D A T$} \\
\hline Pyrasulfotole/bromoxynil & 0.0 & $\mathrm{a}$ & Z & 0.5 & $\mathrm{a}$ & $\mathrm{Z}$ & 1.0 & $\mathrm{a}$ & $\mathrm{Z}$ & 1.4 & $\mathrm{a}$ & Z & 1.4 & $\mathrm{a}$ & $\mathrm{Z}$ & 0.2 \\
\hline SE & 0.1 & & & 0.2 & & & 0.2 & & & 0.3 & & & 0.3 & & & \\
\hline
\end{tabular}

${ }^{a}$ Abbreviations: DAT, days after treatment; UAN, urea ammonium nitrate

${ }^{\mathrm{b}}$ Non-ionic surfactant added to thifensulfuron/tribenuron + MCPA amine $(0.2 \% \mathrm{v} / \mathrm{v})$; ammonium sulfate added to pyrasulfotole/bromoxynil $\left(1.0 \mathrm{~L}\right.$ ha $\left.{ }^{-1}\right)$.

was applied at $200 \mathrm{~L} \mathrm{ha}^{-1}$ using flat fan nozzles. Edwards et al. [7] similarly found that flood nozzles could be effectively used to apply UAN at up to $120 \mathrm{~L} \mathrm{ha}^{-1}$.

Generally, winter wheat injury increased as the UAN carrier volume increased (Table 4). UAN alone, without any herbicide, caused 2, 4, 5 and $6 \%$ visible crop injury 7 DAT at 100, 200, 300 and $400 \mathrm{~L}$ carrier volume $\mathrm{ha}^{-1}$, respectively (Table 4). With herbicide, injury 7 DAT ranged from 3 to 8 , 6 to 12,7 to 14 and 8 to $18 \%$ for carrier volumes of 100 , 200, 300 and $400 \mathrm{~L} \mathrm{ha}^{-1}$, respectively (Table 4). Although winter wheat injury due to herbicide application with a UAN carrier was additive, the extent of damage diminished over time. At 28 DAT, the addition of a herbicide to the UAN carrier did not increase the level of winter wheat injury, except for thifensulfuron/tribenuron + MCPA amine at 100, 200, 300 and $400 \mathrm{~L} \mathrm{ha}^{-1}$ (Table 4). In similar studies, Lutcher and Mahler [12] found significant winter wheat injury when bromoxynil/MCPA was applied using UAN as the carrier. Soltani et al. [11]reported that winter wheat injury of 4, 5 and $5 \%$ at 7 DAT decreased to $0.2,1$ and $4 \%$ by 28 DAT, when bromoxynil/MCPA, dichlorprop/2,4-D and thifensulfuron/tribenuron were applied with $100 \mathrm{~L} \mathrm{ha}^{-1} 28 \%$ UAN, respectively.

Winter wheat height did not decrease in response to application of bromoxynil/MCPA, dichlorprop/2,4-D, pyrasulfotole/bromoxynil (Table 3). In contrast, the application 
of thifensulfuron/tribenuron + MCPA amine caused a decrease of 3\% in winter wheat height (Table 3). Soltani et al. [11] reported that application of bromoxynil/MCPA, dichlorprop/2,4-D and thifensulfuron/tribenuron using UAN as the carrier at a volume of $100 \mathrm{~L} \mathrm{ha}^{-1}$ did not decrease winter wheat height. In experiments where water was used as a carrier, fall application of dichlorprop $+2,4-\mathrm{D}$ reduced winter wheat height by $8 \%$ [13] while spring application of bromoxynil + MCPA dichlorprop $+2,4-\mathrm{D}$ did not reduce wheat height [14].

Bromoxynil/MCPA, dichlorprop/2,4-D, thifensulfuron/tribenuron + MCPA amine and pyrasulfotole/bromoxynil reduced red clover dry weight by 58,94 , 91 and $98 \%$ relative to the untreated control, respectively (Table 3). In studies conducted where UAN was used as the carrier solution, bromoxynil/MCPA, thifensulfuron/tribenuron, dichlorprop/2,4-D and 2,4-D caused no yield reduction $[8,11]$ while bromoxynil + MCPA resulted in a yield decrease [12]. Bradley and Conley [15] also found that the addition of $2,4-\mathrm{D}$ or $20 \%$ UAN to imazamox reduced yields in imidazolinone-resistant wheat, relative to application of imazamox alone. Moreover, application of broadleaf herbicides including 2,4-D, bromoxynil, MCPA and dichlorprop in a water carrier has shown no negative impact on wheat yields when applied at the recommended rate $[14,16]$.

This study examined SRWW tolerance to POST springapplied herbicide with a UAN carrier. In other research, Sikkema et al. [17] demonstrated excellent SRWW tolerance to spring-applied 2, 4-D amine, bromoxynil + MCPA and dichlorprop + 2,4-D, while Brown and Sikkema [14] similarly concluded that crop safety was adequate for spring-applied fluroxypyr + MCPA ester. In the two latter studies, SRWW tolerance was generally matched by that of hard red winter wheat and soft white winter wheat. It is therefore likely that hard red and soft white winter wheat would show similar tolerance to bromoxynil/MCPA and dichlorprop/2,4-D applications in a UAN carrier, however, substantiating research is required for confirmation.

Dichlorprop/2,4-D, thifensulfuron/tribenuron + MCPA amine and pyrasulfotole/bromoxynil reduced red clover establishment (Table 3). Bromoxynil/MCPA, dichlorprop/2,4$\mathrm{D}$, thifensulfuron/tribenuron + MCPA amine and pyrasulfotole/bromoxynil reduced red clover dry weight by $58,94,91$ and $98 \%$ relative to the untreated control, respectively (Table 3). Ivany et al. [18] similarly reported high red clover injury due to bromoxynil/MCPA, thifensulfuron/tribenuron and 2,4-D mixtures when applied to barley (Hordeumvulgare L.) under sown to red clover. UAN treatment reduced clover establishment by more than $50 \%$.

\section{CONCLUSION}

Results of this study indicate that application of bromoxynil/MCPA, dichlorprop/2,4-D, thifensulfuron/tribenuron + MCPA amine or pyrasulfotole/bromoxynil in $28 \%$ UAN carrier will cause injury in winter wheat initially, however, injury is transient with minimal to no impact on wheat height, head distortion and yield. Where present, thifensulfuron/tribenuron + MCPA amine caused more injury than bromoxynil/MCPA, dichlorprop/2, 4-D and pyra- sulfotole/bromoxynil. Herbicide injury when applied in UAN as the carrier was additive and increased as rate of UAN increased. Establishment of red clover was decreased by dichlorprop/2,4-D, thifensulfuron/tribenuron + MCPA amine and pyrasulfotole/bromoxynil. This research suggests that UAN has potential to be used as a herbicide carrier for bromoxynil/MCPA, dichlorprop/2,4-D, thifensulfuron/tribenuron +MCPA amine and bromoxynil/pyrasulfotole for spring POST application in winter wheat. However, it is not recommended for growers who opt to under seed red clover as this practice can reduce legume establishment.

\section{CONFLICT OF INTEREST}

The authors confirm that this article content has no conflict of interest.

\section{ACKNOWLEDGEMENTS}

This research was made possible through funding provided by the Grain Farmers of Ontario. The authors acknowledge the efforts of Todd Cowan for his technical skill and support in these experiments.

\section{REFERENCES}

[1] Agriculture and Agri-Food Canada. Crop profile for winter wheat in Canada. Pesticide Risk Reduction Program, Pest Management Centre, Agriculture and Agri-Food Canada, Building 57, 960 Carling Ave., Ottawa, ON: Canada K1A 0C6 2010.

[2] Alberta Wheat Commission. Winter wheat production manual. Alberta Wheat Commission, \#200 $6815-8^{\text {th }}$ St. NE, Calgary, AB: Canada, T2E 7H7 2013.

[3] Entz MH, Fowler DB. Agronomic performance of winter versus spring wheat. Agronomy J 1991; 83: 527-32.

[4] Cover crops: red clover [website]. Ontario Ministry of Agriculture, Food and Rural Affairs: Queen's Printer for Ontario.; c 20012003[updated 2003 August 25; cited 2014 June 11]. Available from: http://www.omafra.gov.on.ca/english/crops/facts/cover_crops01/redcl over.htm

[5] Gaudin A, Westra S, Loucks CE, Janovicek K, Martin RC, Deen W. Improving resilience of northern field crop systems using interseeded red clover: a review. Agronomy 2013; 3:148-80.

[6] Edwards JT, Arnall DB, Zhang H. Nitrogen fertilizer timing and source affect hard red winter wheat yield, but application method does not. Crop Manag 2009; 8. doi: 10.1094/CM-2009-0511-01-RS

[7] Ontario Ministry of Agriculture, Food and Rural Affairs. Guide to weed control. Publication 75. Queen's Printer for Ontario, Toronto, ON: Canada.

[8] Stahlman PW, Currie RS, El-Hamid MA. Nitrogen carrier and surfactant increase foliar herbicide injury in winter wheat (Triticum aestivum). Weed Technol 1997; 11: 7-12.

[9] Statistical Analysis Systems. The SAS System for Windows, Release 9.2. Statistical Analysis Systems Institute, Cary, NC: USA 2008.

[10] Holzapfel CB, Lafond GP, Brandt SA, May WE, Johnston AM. In-soil banded versus post-seeding liquid nitrogen applications in no-till spring wheat and canola. Can J Plant Sci 2007; 87: 22332 .

[11] Soltani N, Shropshire C, Sikkema P. Urea ammonium nitrate as the carrier for herbicides in winter wheat. Am J Plant Sci 2012; 25: 417-24.

[12] Lutcher LK, Mahler RL. Sources and timing of spring topdress nitrogen on winter wheat in Idaho. Agronomy J 1988; 80: 64854.

[13] Soltani N, Shropshire C, Sikkema PH. Responses of winter wheat (Triticum aestivum L.) to autumn applied post-emergence herbicides. Crop Protect 2006; 25: 346-9.

[14] Sikkema PH, Brown L, Shropshire C, Soltani N. Responses of three types of winter wheat (Triticum aestivum L.) to springapplied post-emergence herbicides. Crop Protect 2007; 5: 715-20. 
[15] Bradley K, Conley S. Influence of imazamox rate and tank-mix combinations on winter annual broadleaf weed control and yield in imidazolinone-resistant wheat. Crop Manag 2006; 5(1). doi: 10.1094/CM-2006-0523-01-RS

[16] Derksen DA, Kirkland KJ, McLennan BR, Hunter JH, Loeppky HA, Bowren KE. Influence of fall and spring herbicide application on winter wheat (Triticum aestivum L.'Norstar'). Can J Plant Sci 1989; 69: 881-8.
[17] Brown L, Sikkema PH. Tolerance of three types of winter wheat (Triticumaestivum L.) to fluroxypyr plus MCPA ester. Can J Plant Sci 2010; 90: 785-9.

[18] Ivany JA, Holmstrom D, Kunelius HT. Effect of herbicides on two species of clover underseeded into barley. Can J Plant Sci 2000; 80: 973-6.

Received: April 08, 2014

Revised: June 19, 2014

Accepted: June 20, 2014

(C) Walsh et al.; Licensee Bentham Open.

This is an open access article licensed under the terms of the Creative Commons Attribution Non-Commercial License (http://creativecommons.org/licenses/by-nc/3.0/) which permits unrestricted, non-commercial use, distribution and reproduction in any medium, provided the work is properly cited. 